ppi $201502 Z U 4645$

Esta publicación cientifica en formato digital es continuidad de la revista impresa ISSN-Versión Impresa 0798-1406 / ISSN-Versión on line 2542-3185Depósito legal pp

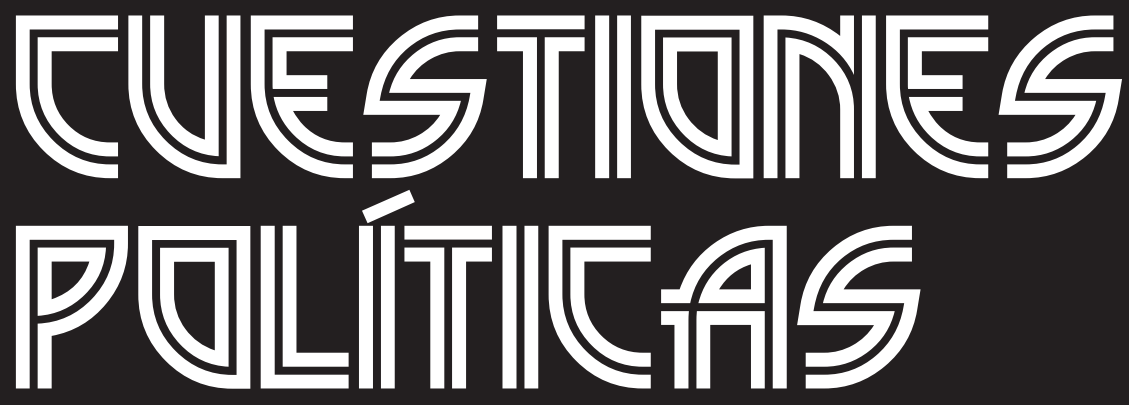

Instituto de Estudios Políticos y Derecho Público "Dr. Humberto J. La Roche' de la Facultad de Ciencias Jurídicas y Políticas de la Universidad del Zulia Maracaibo, Venezuela
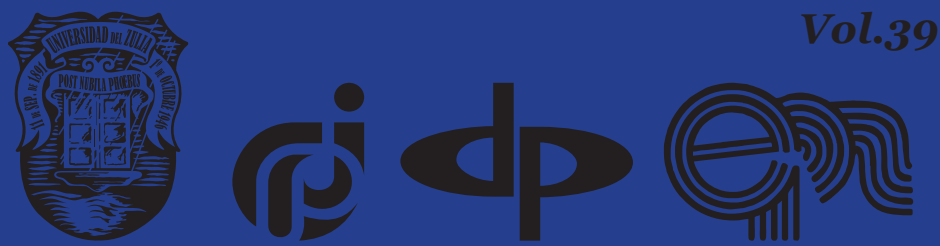


\title{
Modern Threats to the National Security of Ukraine Related to Incomplete Legal Formalization Process of Ukrainian State Border
}

\author{
DOI: https://doi.org/10.46398/cuestpol.3968.56
}

\section{Volodymyr Nikiforenko ${ }^{1 *}$}

\section{Abstract}

The border issue has become particularly urgent for Ukraine since 2014 with the beginning of military aggression by the Russian Federation, the illegal annexation of the Autonomous Republic of Crimea and the city of Sebastopol, as well as the temporary occupation of the part of Ukraine's sovereign territory in the Donetsk and Luhansk regions. The problem of the legal formalization of the Ukrainian-Russian state border requires closer examination in the context of complex relations between two states. This article seeks to analyze the current situation of legal formalization of the Ukrainian state border with neigh bouring countries and highlights the main threats to Ukraine's national security arising from the incomplete process of formalizing the Ukrainian state border with the Russian Federation. It was revealed that the incomplete process of legal formalization of the state border threatened to lose the state part of sovereignty, territorial integrity in sovereign territory. It is concluded that there is a potential threat of escalation of border conflicts and military clashes in Ukraine's border regions, as well as at Ukraine's borders, and the spread of extremist, terrorist, and separatist demonstrations on Ukraine's state border.

Keywords: edge of the state; national security; Russian intervention; Crimea; territorial occupation.

First Deputy Head of the State Border Guard Service of Ukraine, Administration of the State Border Guard Service of Ukraine, Kyiv, Ukraine, ORCID ID: https://orcid.org/oooo-00o3-1452-2312. Email: i797907@gmail.com 


\section{Resumen}

La cuestión fronteriza se ha vuelto particularmente urgente para Ucrania desde 2014 con el comienzo de la agresión militar por parte de Rusia, la anexión ilegal de la República Autónoma de Crimea y la ciudad de Sebastopol, así como la ocupación temporal de la parte del territorio soberano de Ucrania en las regiones de Donetsk y Luhansk. El problema de la formalización legal de la frontera entre Ucrania y Rusia exige un examen más detenido en el contexto de relaciones complejas entre dos Estados. Este artículo busca analizar la situación actual de formalización legal de la frontera del Estado ucraniano con los países de la región y pone de relieve las principales amenazas a su seguridad nacional derivadas del proceso incompleto de formalización de la frontera estatal ucraniana con la Federación rusa. Se reveló que el proceso incompleto de formalización legal de la frontera puede significar pérdida de soberanía e integridad territorial para Ucrania. Se concluye que existe una amenaza potencial de escalada de conflictos fronterizos y enfrentamientos militares en las regiones fronterizas, así como en las fronteras de Ucrania, y la propagación de manifestaciones extremistas, terroristas y separatistas en la frontera estatal de Ucrania.

Palabras clave: borde del estado; seguridad nacional; intervención rusa; Crimea; ocupación territorial.

\section{Introduction}

State border is an important element of the State policy of institutional integration and cultural assimilation (Vrban, 2018). The establishment of State border always has been and will expectadly remain one of strategic national security objectives of each country. Ukraine is not an exception in this respect.

The issue of defining the borders of Ukraine has arisen after the signature of the Declaration of Independence of Ukraine, the dissolution of the former Soviet Union and creation of new independent states. In this connection, on 12 September 1991, the Verkhovna Rada of Ukraine adopted the Law of Ukraine "On Legal Succession of Ukraine" (Verkhovna Rada, 1991). Article 5 states that "State border of the Union of Soviet Socialist Republics separating the territory of Ukraine from other States and the border between the Ukrainian Soviet Socialist Republic, the Byelorussian Soviet Socialist Republic, the Russian Soviet Federative Socialist Republic, the Republic of Moldova as of 16 July 1990 constitute the state border of Ukraine" (Verkhovna Rada, 2003).

Ukraine has joint borders with seven states. Four of them are the European Union Member States (the Republic of Poland, the Slovak 
Republic, Hungary, and Romania). The length of border with the mentioned EU Member States is 1,390,742 km, which is $20 \%$ of the whole border length. Other three States which have joint borders with Ukraine are MemberStates of the Commonwealth of Independent States (the Republic of Moldova, the Republic of Belarus and the Russian Federation). The border length with the CIS Member States is 4,601,24 km, or $65 \%$ of whole length. More than 1,001 km (15\%) of Ukraine's border passes along the boundary of the territorial sea. The longest border segment of Ukraine is the Ukrainian-Russian one and stretches for 2,295.04 km. The shortest border segment of Ukraine is the Ukrainian-Slovak area (98 km). Ukraine is bordered in the Black Sea with the sea areas of Romania, Turkey and the Russian Federation.

Taking into account the uncertain legal status of the Ukrainian-Russian segment of state border, Ukraine has faced a potential threat of the loss of the sovereignty and territorial integrity under direct military intervention of the Russian Federation. It is obvious that the ongoing attempts by the political leadership of the Russian Federation to redefine new state borders in modern world constitute one of the most blatant violations of international law, which in turn could trigger or repeat a territorial dispute between neighbours (Harrison, 2007).

Ukraine remains one of the important contributors to international peace and stability. My state pursues peaceful policies being committed to all international principles of mutual non-use of force or threat of its use. This course of Ukraine is unchanged and fixed, inter alia, in the National Security Strategy of Ukraine. Undoubtedly, peace is a key to Ukraine's development. Peacemaking and the restoration of the sovereignty and territorial integrity of Ukraine within its internationally recognized State border is the highest priority of the State (President of Ukraine, 2020).

Improvment of the effectiveness of State policy in the area of State border and sovereign rights protection has been identified as one of the main directions of the State's foreign and domestic political activities in order to preserve its national interests and security Ukraine in its exclusive maritimeeconomic zone, and also migration which also makes it necessary to examine the problems of the legal formalization of the Ukrainian state border. That is why under nowadays conditions researches regarding search for effective enforcement mechanisms and an optimal model of ensuring national security of the States from internal and external threats gain particular relevance (Kuryliuk and Khalymon, 2020).

\section{Analysis of resent research}

State borders were conceived with the advent of international law, especially after the Peace of Westphalia of 1648 , as a direct delimitation 
of state territories - the division of the world into nation states. They were seen as signs of the territorial integrity and sovereignty of the state. Since then, the state territory looks like a whole entity, separated from neighbours by clear geometric lines. In addition to arguments in favour of self-determination and linguistic separation, claims for acquisition and alteration of borders are also based on the idea of "natural borders".

Border and territorial disputes are worldwide actual topic for scientific research, including the countries of the post-Soviet area. The principles of territorial integrity and the inviolability of borders are central to modern system of international law, they are democratic governing source of international law and norms of a universal character (Corten, 1998).

The problems of territorial disputes remain relevant for both domestic and foreign researchers. In Ukraine, various scholars have devoted attention to the problems of the legal formalization of the state border.

Adamchuk I. studied forms and methods of changing existing interstate borders which were legalized by international law during the interwar period (1918-1939), as well as Soviet compliance with the requirements and norms of existing international law during the reunification of Northern Bukovyna and Transcarpathian Ukraine with Soviet Ukraine (Adamchuk, 2010). In their work, Kyslovskyi and Truhan made a research of the problems of defining the frontier of internal sea waters as a part of sovereign maritime territory with a view to demilitarizing maritime area (Kyslovskyi and Truhan, 2012).

The current condition of public administration in the sphere of legal formalization of the state border was researched by Sitsinskyi V. He made the conclusion that the legal formalization of the state border of Ukraine throughout its length is a key foreign policy priority of national security of Ukraine (Sitsinskyi, 2012).

Sitsinskyi N. noted that the State border of Ukraine is not legally formalized and does not allow the introduction of effective mechanisms of public administration to protect the sovereignty, territorial integrity, and independence of the state. It is also impossible to introduce effective mechanisms for ensuring the regime of the state border, in particular the procedure for its maintenance and the development of the relevant border infrastructure and conduction of economic and environmental activities, ensuring the safety of navigation in border waters, as well as carrying out various industrial activities in the continental shelf and the exclusive (maritime) economic zone of Ukraine (Sitsinskyi, 2014).

The subject of Nick Megoran's research was border and territorial disputes between Kyrgyzstan, Uzbekistan, and Tajikistan. The author studied the problems of the delimitation of national territories and the drawing of borders, as well as the results of the Soviet-era policies that continue to have a complex impact on the region (Megoran, 2004). 


\section{Volodymyr Nikiforenko \\ Modern Threats to the National Security of Ukraine Related to Incomplete Legal Formalization 870 Process of Ukrainian State Border}

The researchers (Nematov, 2018) note that the actions of the leaders of Kyrgyzstan, Uzbekistan and Tajikistan are the classic example of the settlement of complex issues through negotiation and diplomacy and are fully in line with the norms and principles of the United Nations Organization (Megoran, 2007).

As Fang and Li point out, territorial disputes can last for decades, possibly more than a hundred years. Some of those disputes did not end even after hostilities; a defeated party could simply waive its claims. Moreover, states are not always prepared to incur incidental costs for the settlement of such disputes, in view of the considerable costs related with tension and the threat of war (Fang and Li, 2019).

The historical aspects of territorial disputes in Africa have also made significant contributions to the scientific literature on these issues. The book "Demilitarization and Demarcation of borders in Africa" (Wafula, 2013) indicates that border disputes continue to follow African states because of the European perception of the division of territory in Africa during the colonial period (Powell and Wiegand, 2014). Europeans believed that Africans had no state.

As a result, Europeans gained control over African territories that they did not recognize as states. While states are members of international community where mutual interdependence, globalization and non-state actors have an increasing role, the state is still the central actor in the community. So, the most convenient approach for the study of borders is the relationships between states. Their formula is foreign policy that range between war and peace, conflict, and cooperation. Even today, the main aim of State's foreign policy is acquisition of strategic, military, and economic advantages over other states.

Unresolved territorial disputes often lead to military conflicts. In 1990, Saddam Hussein used the old border dispute as a reason for Iraq's invasion of Kuwait, as that country was one of the former Ottoman territories (Tymchenko and Kononenko).

We fully agree with the view of Carter and Goemans who mentioned that the way the borders are established in is important for international stability: borders established within pre-existing internal or external administrative border will cause fewer territorial disputes in the future and have significantly lower risk of militarized confrontation in case of controversy (Carter and Goemans).

Transformation of administrative borders between the Union Republics within the USSR into their state borders based on the uti possidetis principle demonstrate certain maturity of states and their desire to apply the norms of international law. According to international scholars this principle is the right of newly formed states to determine their own borders. It also helps to 
protect the borders of the newly independent states and serves as a shield against further destructions. The uti possidetis principle asserts that: "New states that have gained independence remain with the same borders as they had when they were part of a colonial power" (Hasani, 2003: 7).

The selection of previous administrative borders, both internal and international, effectively minimizes uncertainty and costs, and effectively solves the practical difficulty of consideration all possible boundaries that could be established to separate two states (Marcus, 1996).

A review of scientific literature on Ukraine's border and territorial disputes with neighbouring countries and similar disputes in other countries of both the former Soviet Union and other countries of the world points to several factors which can provoke border conflicts and disputes. Such factors include the influence of third countries or the influence of pseudo-patriotic (nationalist) forces. The existence of such factors could resolve a military conflict between peaceful countries that would not have a diplomatic solution. At the same time, the settlement of issues relating to legal formalization of the state border of Ukraine makes it necessary to conduct further scientific research on this topic.

\section{Historical aspects}

The legal formalization of the Ukrainian state border with the EU Member States was based on the general principle of succession to bilateral international legal treaties between the former USSR and these countries.

Ukraine's current State borders with the Republic of Moldova, the Republic of Belarus and the Russian Federation have been established by bilateral international treaties, which, fixed the transformation of the administrative borders between the union republics within the USSR into their State borders on the basis of the uti possidetis (Tunkin, 1997) principle.

The State border of Ukraine with the Slovak Republic was established by the Agreement between Ukraine and the Slovak Republic on the Common Border of 14 October 1993, with Hungary - by the Agreement between Ukraine and the Republic of Hungary on the regime of the UkrainianHungarian State Border, Cooperation and Mutual Assistance on Border Issues of 19 May 1995, with the Republic of Poland - by the Agreement between Ukraine and the Republic of Poland on the Legal Regime of the Ukrainian-Polish State Border, Cooperation and Mutual Assistance on Border Issues of 12 January 1993.

The line of the State border between Ukraine and Romania was established on the principle of succession, with the exception of the point of junction of the territorial seas, which was not defined in Soviet times and became the subject of negotiations between Romania and independent 


\section{Volodymyr Nikiforenko \\ 872 \\ Modern Threats to the National Security of Ukraine Related to Incomplete Legal Formalization Process of Ukrainian State Border}

Ukraine. As a result of the negotiations, the Agreement between Ukraine and Romania on the Regime of the Ukrainian-Romanian State Border, Cooperation and Mutual Assistance on Border Issues was signed on 17 June 2003. It confirmed the passage of the state border between Ukraine and Romania on the area as it was defined in the Soviet-Romanian treaties and demarcation documents. This Agreement alsodefined the geographical coordinates of the point of intersection of the state borders (territorial seas) of Ukraine and Romania in the Black Sea: $45^{\circ} \mathrm{O}^{\prime} 21^{\prime \prime} \mathrm{N}, 30^{\circ} \mathrm{O} 2^{\prime} 27^{\prime \prime} \mathrm{E}$.

The agreements about the state borders of Ukraine with the the Slovak Republic, Hungary, Poland, and Romania confirmed not only delimitation but also all the demarcation documents between them and the Soviet Union on the principle of succession. Joint inspections of the State border line on the area take place at these stations.

The fact that the process of legal formalization of the common borders with the Russian Federation has not been completed, as well as the events of the past six years, give reason to note that this issue is a threating problem for Ukraine and has a critical importance for its future, sovereignty, and territorial integrity.

\section{State of legal formalization of the Ukrainian-Russian area of border}

The total length of the land border of the Ukrainian-Russian border is $1,974 \mathrm{~km}$, which extends through the territories of Chernihiv, Sumy, Kharkiv, Luhansk and Donetsk regions.

Delimitation of the state border between Ukraine and the Russian Federation was completed in 2003 with the signing of the Agreement between Ukraine and the Russian Federation on the Ukrainian-Russian state border. According to it, the Ukrainian-Russian state border passes as it is indicated in the Description of the passage of the state border between Ukraine and the Russian Federation and depicted by a continuous red line on the maps of the state border between Ukraine and the Russian Federation. Description of the passage of the state border and maps of the state border form an integral part of it. The relevant treaty was registered by Ukraine in the United Nations Secretariat on 1 December 2016, No. 54132 and published by link.

In accordance with Article 2 of the Agreement between Ukraine and the Russian Federation on the Demarcation of the Ukrainian-Russian state border of 17 May 2010, the parties established Joint UkrainianRussian demarcation commission. In addition to the agreement on the Ukrainian-Russian state border and the above-mentioned agreement, the legal formalization basis for the activities of the Joint Ukrainian-Russian 
demarcation commission is the "Regulation on the Joint UkrainianRussian demarcation commission» signed on 21 June 2011 in Kyiv.

Field demarcation commenced on 2 April 2012 the first border sign in the area of the junction of the state borders of Ukraine, Russia and Belarus was installed and officially opened. Totally, there were held 18 meetings of the Joint Ukrainian-Russian demarcation commission. The nineteenth meeting of the Commission scheduled for 18-20 February 2014 in Kyiv didn'ttake place because the Russian Federation delegation did not arrive.

As is known, at the end of February 2014 the Russian Federation grossly violated norms of international law and the provisions of inter-state legal acts on border issues, has carried out an armed annexation of part of the state territory of Ukraine in the Autonomous Republic of Crimea. The entire international community has already severely condemned these irresponsible actions by the Russian side as threatening to the security of the entire European continent. Unfortunately, «strategic partners» from the Russian Federation are once again implementing their annexationist and Anti-Ukrainian plans, the essence of which consists in the military annexation of certain border regions of Ukraine and spread of separatist and extremist sentiments among the population of the state.

Today's actions of Moscow on the common area of the state border represent a particular threat to the sovereignty, territorial integrity, and cathedral of Ukraine. Every day, numerous criminal groups try to enter Ukraine through the Ukrainian-Russian state border. Their aim is to destabilize the domestic political situation in our state. For the first time since Ukraine's independence, a powerful group of military forces and assets on both sides of the border with Russia have been accumulated in full combat and mobilization readiness for military action. In the present conditions of statehood, Ukraine faces with a potential threat of the loss of the sovereignty and territorial integrity of the state in the conditions of a direct military threat from the Russian Federation.

During the period of the Commission's work, graphical projects for the installation of border signs in the Chernihiv-Bryansk region $(222 \mathrm{~km})$ and in the Sumy-Bryansk region $(150 \mathrm{~km})$ were developed and approved. In the first region there were implemented $222 \mathrm{~km}$ of the state border, 106 main and 147 intermediate border signs. In the second region there were implemented $96 \mathrm{~km}$ of the state border, 381 locations for border signs were identified. Graphic projects of border signs places in the Sumy-Kursk region $(299 \mathrm{~km})$ and in the Sumy-Belgorod region $(109 \mathrm{~km})$ are at the final stages of development. They were to be confirmed at the nineteenth meeting of the Commission, which did not take place. Graphical projects for the installation of border signs were not prepared and demarcation work was not started on the areas of the state border within Kharkiv (281 $\mathrm{km})$, Luhansk $(739 \mathrm{~km})$ and Donetsk $(174 \mathrm{~km})$ regions. 
Volodymyr Nikiforenko

874

Modern Threats to the National Security of Ukraine Related to Incomplete Legal Formalization Process of Ukrainian State Border

O. Melnikov (2008) noted that during the delimitation and demarcation work, there were identified number of so-called «crisis points» (the railway track on the area Rozsosh-Chortkove-Milove). It has not been possible to resolve these issues in 12 years. The situation worsened in 2014 with the beginning of military aggression carried out by the Russian Federation.

As of July 2020, the updated composition of the Ukrainian delegation to the Commission has been approved by the Decree of the President of Ukraine «On amendments to the Decrees of the President of Ukraine of 28 April 2011 No 509 and of 31 October 2011 No 1008» No 177/2017 of 5 July 2017.

The process of legal formalization of the Ukrainian-Russian state border and the work of the Commission can be re-established only after the complete cessation of the armed aggression of the Russian Federation and return of control over the Ukrainian-Russian state border and the restoration of constitutional order in the territories of the Donetsk and Luhansk regions which are temporarily occupied by the Russian Federation.

For a long time, the Ukrainian-Russian state border has been actively used by numerous international criminal groups for illegal migration, trafficking in human beings, smuggling, drug trafficking and the illegal movement of weapons, explosives, means of terror across the border and other illegal activities at the border. Consequently, the activities of crossborder criminal groups along the common State border between Ukraine and the Russian Federation have always posed a potential threat to the national security of the state.

As Zhaimagambetov (2015) noted in his research «Russia has proven itself as incapable mediator to solve border disputes».

That is obviously, it is difficult to expect decent behaviour from the Russian Federation in a process of legal formalization of Ukrainian-Russian state border, especially after the annexation of the Autonomous Republic of Crimea and the city of Sevastopol as well as the occupation of part of the territory of Donetsk and Luhansk regions.

As of summer, 2020, the Ministry of Foreign Affairs of Ukraine had taken measures to update and optimize the personal composition of the Ukrainian delegation. A draft Decree of the President of Ukraine «On amendments to the Decree of the President of Ukraine of 31 October 2011 No. 1008» has been sent to the authorities involved (letter of 3 July 2020 No 72/14-4121471). It is obvious that the incomplete status of legal formalization of the state border, the exclusive (maritime) economic zone and the delineation of the Black Sea continental shelf is one of the external threats to national security (Marchenko, 2009). 


\section{State of legal formalization of the Ukrainian-Moldovan area of border}

The state border of Ukraine with the Republic of Moldova was established by the Agreement between Ukraine and the Republic of Moldova on the state border of 18August 1999. After the entry into force of the Agreement on the state Border and in order to implement its provisions, the parties concluded the Regulation on the Demarcation of the state border between Ukraine and the Republic of Moldova of 29 January 2003 (in the form of an intergovernmental agreement).

The demarcation process began in March 2002. In accordance with article 7 of the Agreement, the parties established a Joint UkrainianMoldovan Demarcation Commission.

Unfortunately, the demarcation process has been stalled for a long time because of the political unresolved issues on the part of the self-proclaimed Transnistrian Moldovan Republic. This prevented the beginning of practical work on the demarcation of the central (Transnistrian) Ukrainian-Moldovan area of the state border $(452 \mathrm{~km})$. The demarcation process of this segment of the state border has made significant progress on 29 January 2010. With the participation of the Heads of the foreign affairs of Ukraine and the Republic of Moldova, there was established the first intermediate border sign 0204 in the central section: Velyka Kisnytsa, Iampil area, Vinnytsia region (Sitsinskyi, 2014).

As of March 2020, 66 meetings of the Commission had been held. On the outcomes of work establishment of the border line on the ground was finished: $1,222 \mathrm{~km}$ (99.9\%) of the border line has been established, including $452 \mathrm{~km}$ in the central (Transnistrian) section; 4198 border signs were installed; As of 2020, the Ukrainian-Moldovan border is demarcated at $99.9 \%$.

Problematic issues remain demarcation of the State border in the area of the water-flow dam of the buffer hydro-unit of the Dniester complex hydrounit; demarcation in the area of Giurgiulesti (delimitation points 712-713).

Demarcation of the Ukrainian-Moldovan area of border in regions of the water-flow dam of the buffer hydro-unit of the Dniester complex hydrounit and settlement Giurgiulesti is provided due to the implementation of so-called «package agreements» recorded in the Protocol of the thirteenth meeting of the Intergovernmental Ukrainian-Moldovan Mixed Commission on Trade and Economic Cooperation (10-11 November 2011, Chisinau).

Next to the demarcation, the mutual recognition and formalization of the ownership rights of Ukraine and the Republic of Moldova over the facilities located in the territories of the parties, including part of the Dniester complex hydro-unit, located on the territory of the Republic of 


\section{Volodymyr Nikiforenko \\ Modern Threats to the National Security of Ukraine Related to Incomplete Legal Formalization 876 Process of Ukrainian State Border}

Moldova, and the issue of ensuring the proper functioning of the Dniester complex hydro-unit belong to the "package arrangements".

Determination of the midpoint of the hydro technical structures - the water-flow dam of the buffer reservoir of the Dniester complex hydro-unit - is a technical issue which is currently being considered in the Working Group on reciprocal processing of ownership in accordance with the Protocol of the 14th meeting of the Intergovernmental Ukrainian-Moldovan Mixed Commission on Trade and Economic Cooperation (held on 18-19 September 2017 in Odessa).

Joint Ukrainian-Moldovan Demarcation Commission prepares draft decisions on the demarcation of the state border in Dniester complex hydrounit and settlement Giurgiulesti after receiving from the authorized state bodies of Ukraine and the Republic of Moldova the specific parameters of the midpoint of the hydro technical structures.

The issue of the final demarcation documents is a derivative one: they can be finalized in a relatively short time, provided that the problem of the Dniester complex hydro-unit and settlement Giurgiulesti will be resolved.

The problems arose due to the fact that the cartographers of the Soviet Union never considered the established borders as borders of independent republics, since their planning approaches were considered on a uniform basis from the point of view of water supply, gas supply and transport networks. In addition, industrial, transport and agricultural projects of one republic could be freely extended to the territory of a neighbouring republic (Megoran, 2004).

\section{State of legal formalization of the Ukrainian-Belarusian area of border}

The state border of Ukraine with the Republic of Belarus was established by the Agreement between Ukraine and the Republic of Belarus of 12 May 1997. Ukraine ratified the agreement on 18 July 1997 and the Republic of Belarus in 2010. The Agreement entered into force on 18 June 2013.

To implement its provisions, the parties concluded an Agreement between the Cabinet of Ministers of Ukraine and the Government of the Republic of Belarus on the approval of the Regulation on the Demarcation of the state border between Ukraine and the Republic of Belarus of 30 July 2014.

In accordance with article 3 of Agreement on state border, the demarcation of the state border between the parties shall be carried out by a Joint Commission. The Joint Commission shall operate under the Regulation on the Demarcation of the state border between Ukraine and 
Republic of Belarus, which shall be approved by the Governments of the parties.

Since 24 June 2014, field work has begun on establishment of the state border line and the identification of border signs locations. 23 meetings of the Joint Ukrainian-Belarusian Demarcation Commission were held.

As of July 2020, project for the placement of border signs at the state border $(1084.2 \mathrm{~km}$ ) was developed; $873 \mathrm{~km}$ of border has been established on the ground; defined 1,944 sites for the installation of border signs, including 24 in 2019; 416 border signs installed by the Ukrainian side; the coordinates and heights of 693 border signs have been determined; a joint geodetic network along the state border has been established; work has been done on the installation and development of the Ukrainian border pillar of the border sign «Bug» (trilateral junction point of the borders of Ukraine, the Republic of Belarus and the Republic of Poland).

However, there are concerns about the recent social and political occurrences in the Republic of Belarus caused by the results of the presidential elections which have not been recognized by the international community because of massive violations. Minister for Foreign Affairs of Ukraine Dmytro Kuleba (2020) stated that «in view of the electoral campaign in Belarus and further occurrences, the «inauguration» of Lukashenko O. did not signify his recognition as the legitimate head of the Belarus». The official reaction of the Ukrainian authorities to the results of the elections, and the response of the Ministry of Foreign Affairs of the Republic of Belarus, could jeopardize the completion of the procedure for the legal formalization of the Ukrainian-Belarusian area of the state border.

\section{Conclusions}

An analysis of the legal formalization for Ukraine's state border with neighbouring countries makes it possible to identify the most significant threats to Ukraine's national security.

Firstly, the incomplete process of legal formalization of the state border threatens to lose the state part of sovereignty, territorial integrity in the sovereign territory. This threat is caused by the intensive politicization of issues the state-territorial structure of certain regions of Ukraine, incitement of separatist and extremist sentiments among the population of the border areas by some neighboring countries intending to revise the existing and regulatory common areas of state borders.

Secondly, there is a significant obstacle to the realization of the strategic foreign policy direction of the state towards European integration. Indeed, one of the main conditions for a State's accession to the European Union is the settlement of issues relating to the legal formalization of the state border and the absence of territorial claims by neighbouring states. 


\section{Volodymyr Nikiforenko \\ Modern Threats to the National Security of Ukraine Related to Incomplete Legal Formalization Process of Ukrainian State Border}

Thirdly, there is a potential threat of escalation of border conflicts and military confrontations in the border regions of Ukraine, as well as at the borders of Ukraine, and of the spread of extremist, terrorist, and separatist manifestations on the state border of Ukraine. Separatism poses a threat to the inviolability of the borders established in accordance with the norms of international law and, consequently, to the political, economic, and territorial security of the entire European space (Litvinenko, 2018).

Fourthly, a significant threat to the national security of Ukraine is the low level of organizational, logistical and financial support for the activities of the Ukrainian state authorities responsible for the legal formalization of the State border, as well as insufficient equipment and resources for military and law enforcement agencies to effectively counter crimes of a cross-border nature and protect national interests at the state border and in the exclusive (maritime) economic zone of Ukraine. The process of delimitation and demarcation of the state border has been considerably hindered by numerous cases of unresolved inter-state property relations and the procedure for managing on border facilities and waters.

Fifthly, there is the potential threat of the loss of the sovereignty and territorial integrity of a state in the situation of direct military aggression by the Russian Federation. The undefined legal status of the common part of the State border of Ukraine with the Russian Federation is potentially dangerous and could become a precondition for Ukraine to lose part of the state territory on the border with Russia.

\section{Bibliographic References}

ADAMCHUK, Igor. 2010. International legal recognition of the State border of Ukraine with Romania and Czechoslovakia (1939-1947). Apriori. Lviv, Ukraine.

AGREEMENT BETWEEN THE CABINET OF MINISTERS OF UKRAINE AND THE GOVERNMENT OF THE REPUBLIC OF BELARUS. 2014. On the approval of the Regulation on the Demarcation of the state border between Ukraine and Republic of Belarus. Available online. In: https:// cutt.ly/Qf8ICDz. Consultation date: 10/02/2020.

AGREEMENT BETWEEN UKRAINE AND ROMANIA. 2003. On the Regime of the Ukrainian-Romanian State Border, Cooperation and Mutual Assistance on Border Issues. Available online. In: https://cutt.ly/ Zfolyga. Consultation date: 10/02/2020.

AGREEMENT BETWEEN UKRAINE AND THE REPUBLIC OF BELARUS ON THE STATE BORDER. 1997. Available online. In: https://cutt. ly/7f3QQIy. Consultation date: 10/02/2020. 
AGREEMENTBETWEEN UKRAINEANDTHE REPUBLICOF HUNGARYON THE REGIME OF THE UKRAINIAN-HUNGARIAN STATE BORDER, COOPERATION AND MUTUAL ASSISTANCE ON BORDER ISSUES. 1995. Available online. In: https://cutt.ly/pfoUVIr. Consultation date: 10/02/2020.

AGREEMENT BETWEEN UKRAINE AND THE REPUBLIC OF MOLDOVA ON THE STATE BORDER. 1999. Available online. In: https://cutt. ly/9f3TKpW. Consultation date: 10/02/2020.

AGREEMENT BETWEEN UKRAINE AND THE REPUBLIC OF POLAND. 1993. On the Legal Regime of the Ukrainian-Polish State Border, Cooperation and Mutual Assistance on Border Issues. Available online. In: https://cutt.ly/4foIrnN. Consultation date: 10/02/2020.

AGREEMENT BETWEEN UKRAINE AND THE RUSSIAN FEDERATION ON THE UKRAINIAN-RUSSIAN STATE BORDER. 2003. Available online. In: https://cutt.ly/Of4mfUx. Consultation date: 10/02/2020.

AGREEMENT BETWEEN UKRAINE AND THE SLOVAK REPUBLIC ON THE COMMON BORDER. 1993. Available online. In: https://cutt.ly/ lfoWsOr. Consultation date: 10/02/2020.

CARTER, David; GOEMANS, Henry. 2011. "The Making of the Territorial Order: New Borders and the Emergence of Interstate Conflict" In: International Organization. No. 2, No. 65, pp. 275-309.

CORTEN, Olivier. 1998. "Droit des peuples à disposer d'eux-memes et uti possidetis: deux faces d'une meme medaille?" In: Revue Belge de Droit International. No. 1, pp. 161-189.

FANG, Songying; LI, Xiaojun. 2019. "Historical Ownership and Territorial Disputes" In: The Journal of Politics. Vol. 1, No. 82, pp. 345-360.

HARRISON, Wagner. 2007. War and the State; The Theory of International Politics. Ann Arbor, MI: University of Michigan Press. Michigan, USA.

HASANI, Elliot. 2003. "Uti Possidetis Juris: From Rome to Kosovo" In: Fletcher Forum of World Affairs, Summer/Fall. No. 85, pp.1-9.

KURYLIUK, Yuriy; KHALYMON, Serhii. 2020. "Criminal profile of migrants' smuggler across the State Border of Ukraine” In: Amazonia Investiga. Vol. 9, No. 27, pp. 195-208.

KYSLOVSKYI, Vasyl; TRUHAN, Mykola. 2011. "Maritime zones of national jurisdiction of Ukraine" In: Bulletin of Geodesy and Cartography. No. 6, pp. 20-25. 
Volodymyr Nikiforenko

880

Modern Threats to the National Security of Ukraine Related to Incomplete Legal Formalization Process of Ukrainian State Border

KYSLOVSKYI, Vasyl; TRUHAN, Mykola. 2012. "Internal sea waters of Ukraine”. In: Bulletin of Geodesy and Cartography. No. 4, pp. 18-25.

LITVINENKO, Kyryl. 2018. Humanitarian factors of generating separatist movements in Ukraine. Scientific Thought. Kyiv, Ukraine.

MARCHENKO, Borys. 2009. Administrative activities of the State Border Service of Ukraine. Legal Help. Dnipropetrovsk, Ukraine.

MARCUS, Andrew. 1996. "Border Disputes Continue to Roil Mideast-Despite Arab-Israeli Moves, Disputes Abound" In: Wall Street Journal. Available online. In: https://cutt.ly/Zf3WnoB. Consultation date: 10/02/2020.

MEGORAN, Nick. 2004. "The Critical Geopolitics of the UzbekistanKyrgyzstan Ferghana Valley Boundary Dispute, 1999-2000" In: Political Geography. No. 6, No. 23, pp. 731-764.

MEGORAN, Nick. 2007. “On Researching 'Ethnic Conflict': Epistemology, Politics, and a Central Asian Boundary Dispute" In: Europe-Asia Studies. Vol. 2, No. 59, p. 253-277.

MELNIKOV, Olexandr. 2008. "On the issue of contractual and legal registration of the state border of Ukraine" In: University scientific notes. Vol. 2, No. 26, pp. 27-33.

NEMATOV, Igor. 2018. "Legal registration of the state border is a concrete result of the foreign policy of Uzbekistan" In: International Relations: Politics, Economics, Law. No. 3, pp. 5-10.

POWELL, Edgar; WIEGAND, Krista. 2014. "Strategic selection: Political and legal mechanisms of territorial dispute resolution" In: Journal of Peace Research. Vol. 3, No. 51, pp. 361-374.

PRESIDENT of Ukraine. 2020. Decree "National security strategy of Ukraine" No 392/2020 of 14.09.2020 Available online.In:https://cutt.ly/7f8DVge Consultation date: 16/09/2020.

SITSINSKYI, Vitaliy. 2012. "Analysis of condition of public administration in the sphere of legal formalization of the state border of Ukraine" In: Investment: practices and experiences. No. 22, pp.113-116.

SITSINSKYI, Vitaliy. 2014. "The analysis of the current state of the legal registration of the state border of Ukraine" In: Investment: practices and experiences. No. 18, pp. 217-220.

TSYMBRIVSKYI, Taras. 2008. Respect for the principles of territorial integrity and the inviolability of borders in international law. In: Scientific Thought: Kyiv, Ukraine. 
TUNKIN, Harry. 1997. International law: Principles of public international law, $415 \mathrm{p}$.

TYMCHENKO, Lyubov; KONONENKO, Volodymyr. 2020. "The legitimacy of acquisition of state territory" In: Juridical Tribune. Vol. 1, No. 10, pp. 149-161.

VERKHOVNA RADA OF UKRAINE. 1991. The Law of Ukraine 'On legal succession of Ukraine' No 1543-XII of 12.09.1991. Available online. In: https://cutt.ly/ff8D14O.Consultation date: 10/02/2020.

VERKHOVNA RADA OF UKRAINE. 2003. Regulation on the Demarcation of the state border between Ukraine and the Republic of Moldova: Law of Ukraine N 1372-IV of 10 December 2003. Available online. In: https:// cutt.ly/lf3TB5Z. Consultation date: 10/02/2020.

VRBAN, Dmytro. 2018. "Borders as an interdisciplinary problem: territoriality and identity - past and present” In: Pravni vjesnik god. Vol. 1, No. 34, pp. 9-50.

WAFULA, Ondine. 2013. "The Purpose and Functions of International Boundaries: with Specific Reference to Africa". In: Delimitation and Demarcation Boundaries in Africa / ed. Addis Ababa. Ethiopia: Commission of the African Union, Department of Peace and Security.

ZHAIMAGAMBETOV, Semen. 2015. The Protracted Border and Territorial Disputes between Kyrgyzstan and Its Neighbors. Master's Thesis Fort Leavenworth, Kansas. Available online. In: https://apps.dtic.mil/sti/ pdfs/ADA623960.pdf Consultation date: 10/02/2020. 

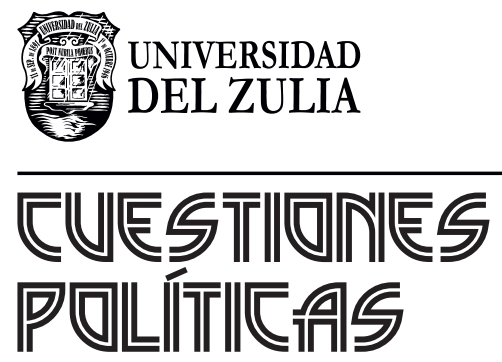

Vol.39 No 68

Esta revista fue editada en formato digital y publicada en enero de 2021, por el Fondo Editorial Serbiluz, Universidad del Zulia. Maracaibo-Venezuela 